\title{
Upregulation of inflammatory genes in the nasal mucosa of patients undergoing endonasal dacryocystorhinostomy
}

This article was published in the following Dove Press journal:

Clinical Ophthalmology

25 April 2014

Number of times this article has been viewed

\author{
Elina Penttilä \\ Juha MT Hyttinen² \\ Maria Hytti ${ }^{2}$ \\ Anu Kauppinen ${ }^{2,3}$ \\ Grigori Smirnov ${ }^{1,4}$ \\ Henri Tuomilehto ${ }^{1,4}$ \\ Juha Seppä' \\ Juhani Nuutinen' \\ Kai Kaarniranta ${ }^{2,3}$ \\ 'Department of Otorhinolaryngology, \\ Kuopio University Hospital, and \\ Institute of Clinical Medicine, \\ University of Eastern Finland, \\ ${ }^{2}$ Department of Ophthalmology, \\ Institute of Clinical Medicine, \\ University of Eastern Finland, \\ ${ }^{3}$ Department of Ophthalmology, \\ Kuopio University Hospital, ${ }^{4}$ Oivauni \\ Sleep Clinic, Kuopio, Finland
}

Correspondence: Elina Penttilä

Department of Otorhinolaryngology,

Kuopio University Hospital, PO Box 1777 ,

FIN-702II, Kuopio, Finland

$\mathrm{Tel}+358$ I7I7 502।

Fax +35817172509

Email elina.penttila@kuh.fi
Background: Epiphora is a common complaint of nasolacrimal duct obstruction (NLDO) in adults. The precise pathogenesis of NLDO is still unknown, but inflammatory processes are believed to be predisposing factors. Endoscopic dacryocystorhinostomy (EN-DCR) is an effective surgical technique for treating symptomatic NLDO. The purpose of the procedure is to relieve the patient's symptoms by creating an opening, ie, a rhinostoma, between the lacrimal sac and the nasal cavity. Although the success rates after EN-DCR are high, the procedure sometimes fails due to onset of a fibrotic process at the rhinostomy site. The aim of this prospective comparative study was to investigate inflammation-related gene expression in the nasal mucosa at the rhinostomy site.

Methods: Ten participants were consecutively recruited from eligible adult patients who underwent primary powered EN-DCR (five patients) or septoplasty (five controls). Nasal mucosa specimens were taken from the rhinostomy site at the beginning of surgery for analysis of gene expression. Specimens were taken from the same site on the lateral nasal wall for controls. Quantitative reverse transcription polymerase chain reaction (qRT-PCR) was performed for the inflammatory genes interleukin (IL)-6, IL-1 $\beta$, and CCL2, and because of a clear trend of increased inflammation in the EN-DCR samples, a wider PCR array was performed to compare inflammation-related gene expression in EN-DCR subjects and corresponding controls.

Results: Our qRT-PCR results revealed a clear trend of increased transcription of $I L-6, I L-1 \beta$, and CCL2 $(P=0.03)$. The same trend was also evident in the PCR array, which additionally revealed notable differences between EN-DCR subjects and controls with regard to expression of several other inflammation-related mediators. At 6-month follow-up, the success rate after primary EN-DCR was $60 \%$, ie, in three of five patients.

Conclusion: The present study demonstrates that there is an intense inflammation gene expression response in the nasal mucosa of patients undergoing EN-DCR.

Keywords: epiphora, fibrosis, dacryocystorhinostomy, gene expression, inflammation, nasolacrimal duct obstruction

\section{Introduction}

Epiphora, ie, tearing of the eye, is a common complaint, particularly in the elderly, the extent of which can vary from minor inconvenience to significant social embarrassment. The common cause of epiphora and discharge from the eye in adults is nasolacrimal duct obstruction (NLDO). The pathogenesis of NLDO is unknown, but the process is characterized by gradual inflammation and subsequent fibrosis of the nasolacrimal duct, which may lead to obstruction of the lacrimal pathway. ${ }^{1,2}$ Endoscopic dacryocystorhinostomy (EN-DCR) is an effective and safe surgical technique for treating symptomatic lower lacrimal pathway obstruction and dacryocystitis in cases where 
there is no response to conservative treatment. The purpose of the procedure is to create a bypass, ie, a rhinostoma, between the lacrimal sac and the nasal cavity. The success of primary EN-DCR has been reported to be high, varying between $74 \%$ and $94 \% .{ }^{3}$ However, the procedure sometimes fails, and the most common reason for this is scarring of the rhinostoma. ${ }^{4,5}$ The granulation tissue and scar formation is thought to be linked to the biology of wound healing in the nasal mucosa (Figure 1). ${ }^{6}$ There have been several histopathological studies reporting chronic inflammation and fibrosis in specimens taken from the nasal mucosa during dacryocystorhinostomy, ${ }^{7-9}$ and various histopathological features related to chronic inflammation may also play a role in the outcome of EN-DCR. ${ }^{9,10}$ However, inflammatory signaling molecules in the nasal mucosa of patients with NLDO have been poorly investigated. Smirnov et al demonstrated that high expression of heat shock protein 47 , a regulator of fibrosis, might predict a poor surgical result after EN-DCR. ${ }^{11}$ Further, these biological factors are important when investigating potential targets for development of antifibrotic therapy. This is of importance, given that there are no effective antifibrotic drugs available to target fibrogenic factors or to block their receptors. ${ }^{12}$ The aim of this prospective comparative study was to investigate the inflammatory gene expression profile at the rhinostomy site in patients undergoing EN-DCR.

\section{Patients and methods}

\section{Patients}

Five study subjects were consecutively recruited from adult patients who underwent primary EN-DCR due to epiphora or recurrent infection of the lacrimal sac between May and August 2012. Five control subjects were also recruited from eligible patients who underwent septoplasty during the same

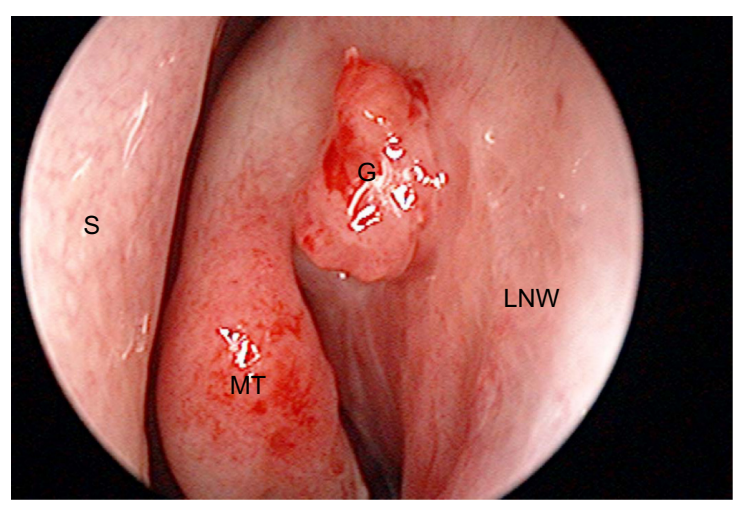

Figure I Excessive granulation formation over the hinostomy site.

Abbreviations: G, granulation; LNW, lateral nasal wall; MT, middle turbinate; S, septum. time period. Patients undergoing septoplasty were selected as controls because their indication for surgery was a septal deformity not associated with any inflammatory or infectious process. All the operations were performed in the Department of Otorhinolaryngology at Kuopio University Hospital, in Kuopio, Finland. Patients were eligible for enrollment if they were adults (age $>18$ years) and if their American Society of Anesthesiologists physical status score was I-III. ${ }^{13}$ Exclusion criteria were presacral obstruction, malignancy in the paranasal sinuses, nasal cavity, or lacrimal pathway, mental disability, pregnancy, or breast-feeding. Patients who underwent septoplasty were not eligible for participation as controls when there was a risk of postoperative adhesions due to the presence of a narrow nasal cavity or where there was a history of recurrent or chronic paranasal infections. The patient demographics are shown in Table 1 . There were no dropouts during the 6-month follow-up period. This study was approved by the research ethics committee at the District Hospital of Northern Savo, Kuopio, Finland. The patients were given oral and written information about the trial protocol, and all provided their written consent.

\section{Assessments}

At the preoperative visit and 1-week, 2-month, and 6-month postoperative visits, an objective assessment was performed by an otorhinolaryngologist who performed lacrimal irrigation and nasal endoscopy, and the findings in the nasal cavity were evaluated using the Lund-MacKay staging system. ${ }^{14}$ A subjective assessment was performed using the Nasolacrimal Duct Symptom Score questionnaire. ${ }^{15}$ The surgical outcome was considered successful if saline solution freely reached the nose during lacrimal irrigation and if there was relief of symptoms.

Table I Baseline demographics of the study population, with data shown as the mean (standard deviation) or number of cases

\begin{tabular}{|c|c|c|}
\hline & Patients $(n=5)$ & Controls $(n=7)$ \\
\hline \multicolumn{3}{|l|}{ Sex } \\
\hline Male & & 5 \\
\hline Female & 5 & 2 \\
\hline Age & $79(4)$ & $37(4)$ \\
\hline \multicolumn{3}{|c|}{ Indication of surgery } \\
\hline Dacryostenosis & I & \\
\hline Dacryocystitis & 4 & \\
\hline \multicolumn{3}{|c|}{ History of chronic rhinosinusitis } \\
\hline Smoking & & 2 \\
\hline Asthma & I & \\
\hline Allergic rhinitis & & 2 \\
\hline Nasal polyposis & I & \\
\hline
\end{tabular}




\section{Operative technique}

Standardized general anesthesia was used. Nasal mucosa specimens were taken from over the rhinostomy site at the onset of the surgery for analysis of gene expression. The control specimens were taken from the lateral nasal wall at exactly the same site. The standardized, detailed endoscopic powered instrumentation technique used and the postoperative care have been described elsewhere. ${ }^{16}$ No stents were used.

\section{Quantitative reverse transcription polymerase chain reaction ( $q R T-P C R$ ) for inflammatory cytokine genes}

Human tissue samples reserved for RNA extraction from five patients undergoing EN-DCR surgery and five control patients were placed immediately into liquid nitrogen and thereafter stored at $-70^{\circ} \mathrm{C}$. RNA was extracted from tissue samples using an RNeasy ${ }^{\circledR}$ mini kit (74104; Qiagen, Valencia, CA, USA), according to the manufacturer's instructions.

First, the tissue pieces were ground mechanically using a glass pestle homogenizer, including the kit buffer, and chilling the homogenizer on ice. The procedure also included a separate RNase-free DNase I treatment (79254; Qiagen) in the extraction column, as described in the kit protocol. Quantity and quality control of the extracted RNA was performed by spectrophotometric analysis.

Next, 500 ng of extracted RNA was reverse-transcribed to generate the corresponding DNA using a SuperScript ${ }^{\circledR}$ III first strand synthesis system (Life Technologies, Carlsbad, CA, USA). In brief, the protocol was as follows: $500 \mathrm{ng}$ of purified RNA in $11 \mu \mathrm{L}$ of RNase-free water was incubated with $50 \mathrm{ng}$ random hexamers and $10 \mathrm{nmol}$ dNTPs (deoxynucleotide triphosphates) for 5 minutes at $65^{\circ} \mathrm{C} ; 100 \mathrm{nM}$ DTT (dithiothreitol), $40 \mathrm{U}^{\mathrm{RNAse}} \mathrm{OUT}^{\circledR}$ (Life Technologies), and $200 \mathrm{U}$ SuperScript ${ }^{\circledR}$ III reverse transcriptase were then added to the reaction, along with the appropriate amount of $5 \times$ First Strand Reaction Buffer. The complete reaction was subsequently incubated at $50^{\circ} \mathrm{C}$ for 50 minutes, after which the enzymes were inactivated at $70^{\circ} \mathrm{C}$ for 15 minutes. The generated complementary DNA (cDNA) samples were used immediately for analysis by qRT-PCR. SYBR ${ }^{\circledR}$ Green Real-Time PCR Master Mix (Life Technologies) and specific primer pairs for human interleukin (IL)-6, IL-1 $\beta$, chemokine (C-C motif) ligand 2 (CCL2), and $\beta$-actin were used to determine the relative messenger $(\mathrm{m})$ RNA expression in the samples. For $I L-6$, the primer pairs were forward, 5'-AGT GAG GAA CAA GCC AGA GC-3' and reverse, $5^{\prime}$-CAG GGG TGG TTA TTG CAT CT-3'; for $I L-1 \beta$, the primer pairs were forward, $5^{\prime}$-AAA AGC TTG GTG ATG

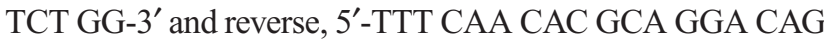

G-3'; for $C C L 2$, the primers were forward, $5^{\prime}$-CTC ATA GCA GCC ACC TTC ATT C-3' and reverse, $5^{\prime}$-TCA CAG CTT CTT TGG GACACT T-3'; and for $\beta$-actin, the primers were forward, 5'-GGA TGC AGA AGG AGA TCA CTG-3' and reverse, 5'-CGA TCC ACA CGG AGT ACT TG-3'. The primers were sourced from Oligomer Oy, Helsinki, Finland. The qRT-PCR reaction was run on an ABI Prism ${ }^{\circledR} 7500$ Thermocycler (Life Technologies) using standard conditions. The data were analyzed using the $\Delta \Delta \mathrm{Ct}$ method ${ }^{17}$ and normalized using human $\beta$-actin expression as an internal control.

\section{PCR array study for inflammatory response gene expression}

cDNA for the array analysis was prepared using an $\mathrm{RT}^{2}$ PreAMP cDNA synthesis kit (330451; Qiagen) following the manufacturer's instructions. For both septoplasty and EN-DCR, five individually extracted RNAs were mixed in equal amounts (1 $\mu \mathrm{g}$ total, $200 \mathrm{ng}$ of each) to provide templates for separate cDNA syntheses. A 96-well RT ${ }^{2}$ ProfilerTM PCR Array for Human Inflammatory Response and Autoimmunity (PAHS077Z; SABiosciences/Qiagen) was used for the inflammation gene expression analysis, including the wells for control reactions. The SYBR ${ }^{\circledR}$ Green (Life Technologies) fluorescence detection methodology was employed. Thus, two one-plate runs were performed, ie, one for the septoplasty controls and the other for the EN-DCR samples. An Applied Biosystems 7500 Real-Time PCR System (Life Technologies) was used for PCR array amplification. All the quality control requirements stipulated by the manufacturer of the array were fulfilled in both PCR runs (including genomic DNA control, cDNA synthesis control, and positive PCR controls). The data were analyzed using the $\Delta \Delta \mathrm{Ct}$ method ${ }^{17}$ and normalized using human glyceraldehyde phosphate dehydrogenase expression as an internal control.

\section{Results}

The overall success rate after primary EN-DCR was $60 \%$ (3/5 patients) at the 6-month follow-up. On nasal endoscopy, the two failed patients showed tight fibrous scarring over the rhinostomy site, and one also had severe synechiae. Otherwise, there were no abnormal endoscopic findings according to the Lund-MacKay staging system. ${ }^{14}$ No other intraoperative or postoperative complications occurred during the study period.

\section{Inflammation-related gene expression profiling using PCR}

qRT-PCR showed that gene expression for all inflammatory markers analyzed, ie, $I L-6(P=0.08), I L-1 \beta(P=0.6)$, and 
CCL2 $(P=0.03)$, was increased in the EN-DCR samples, but statistical significance was achieved only for CCL2 (Figure 2). Due to a clear trend of increased inflammation in the EN-DCR samples, we performed a wider PCR array for inflammatory markers. Interestingly, there were notable differences between the groups with regard to inflammatory mediators (Table 2). The most significant findings in the EN-DCR samples when compared with controls were increased gene expression of the following: E-selectin (6.33-fold), IL-6 (5.23-fold), CCL16 (5.02-fold), tumor necrosis factor (TNF, 4.51-fold), CCL2 (3.77-fold), and CXCL3 (3.0-fold). On the other hand, notably decreased gene expression in EN-DCR samples over the controls was seen for: nitric oxide synthase 2 (0.17-fold), $I L-8$ (0.28-fold), CXCL1 (0.29-fold), IL-1 receptor antagonist (0.31-fold), CCR3 (0.32-fold), and FASLG (Fas ligand TNF superfamily member 6) (0.35-fold).

\section{Discussion}

Our qRT-PCR results showed a clear trend toward increased transcription of $I L-6, I L-1 \beta$, and CCL2. This finding was evident also from the PCR array, which additionally revealed notable differences in expression of several other inflammation-related mediators. There was a clearly increased expression of E-selectin mRNA, indicating an endothelial cell response in samples isolated from patients undergoing EN-DCR. By relatively weak carbohydrate interactions, E-selectin stimulates blood leukocytes to slow down and roll along the endothelium before their transmigration through the endothelium into the tissue. ${ }^{18,19}$ The endothelium can become activated by bacterial lipopolysaccharide, but in the case of NLDO, the activation is more probably mediated by proinflammatory cytokines, such as IL-1 and TNF- $\alpha$. IL- $1 \beta$ and TNF- $\alpha$ together with a third acute phase protein, IL-6, are pleiotropic cytokines exerting a variety of effects on cellular function. In addition to contributing to acute and chronic inflammation, they have all been associated with the process of fibrosis. ${ }^{20,21}$ The continuing presence of inflammation and subsequent fibrosis, in turn, are considered to be the ultimate reason for NLDO. ${ }^{1,22}$

In acute inflammation, neutrophils are the primary leukocytes attracted to the inflammatory site. ${ }^{22}$ In response to chemokines such as IL-8, neutrophils express their IL-6 receptors which activate endothelial cells to decrease their IL-8 production and to favor production of CCL2, which attracts monocytes in particular. ${ }^{20}$ The decreased expression of IL- 8 mRNA and increased expression of CCL2 in our NLDO samples suggest that the inflammation has passed through its initiation phase. The increased gene expression of CCL16, CXCL3, CCL13, and CCL3 in NLDO samples compared with those in controls also supports the transition toward a mononuclear cell type-dominated response. ${ }^{23-26}$ Our present results are in line with previous findings that inflammation is involved in the pathogenesis of NLDO. ${ }^{1,2}$

Nuclear factor kappa B $(\mathrm{NF}-\kappa \mathrm{B})$ is a major transcription factor regulating the expression of many inflammation-related genes. ${ }^{27}$ In addition to the induction of E-selectin, ${ }^{19} \mathrm{NF}-\kappa \mathrm{B}$ plays an important role in the expression of other genes,
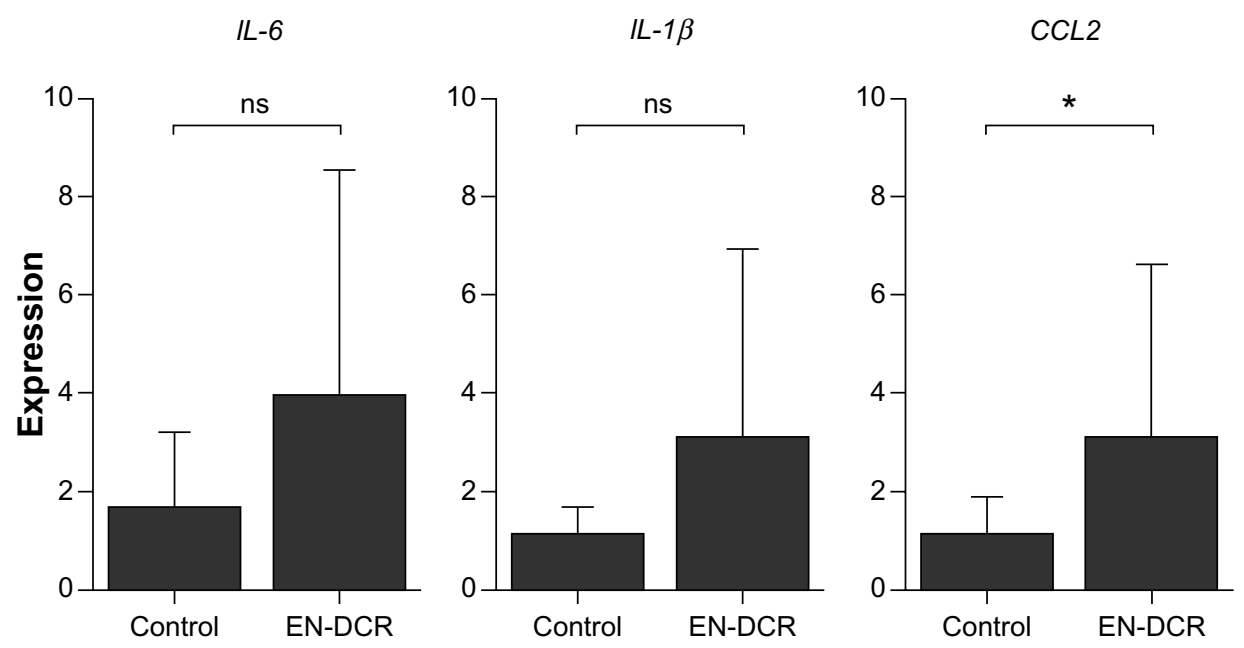

Figure 2 Expression of IL-6, IL-I $\beta$, and CCL2 mRNA in tissue samples of subjects undergoing either septoplasty (control) or EN-DCR surgery.

Notes: The analysis was performed with qRT-PCR. Results are shown as mean \pm SEM of five individual samples, and four parallel measurements were performed from each sample. ${ }^{*} P<0.05, \mathrm{~ns}=$ not significant, Mann-Whitney U-test.

Abbreviations: IL, interleukin; mRNA, messenger RNA; EN-DCR, endoscopic dacryocystorhinostomy; qRT-PCR, quantitative reverse transcription polymerase chain reaction; SEM, standard error of the mean; CCL2, chemokine (C-C motif) ligand 2. 
Table 2 Differences in expression of immune response-related genes analyzed by qRT-PCR array

\begin{tabular}{|c|c|c|}
\hline A & $\begin{array}{l}\text { Genes with markedly increased } \\
\text { expression }\end{array}$ & $\geq 1.5 x$ \\
\hline Gene & Gene name & $\begin{array}{l}\text { Increase } \\
x \text {-fold }\end{array}$ \\
\hline SELE & E-Selectin & 6.33 \\
\hline IL-6 & Interleukin-6 & 5.23 \\
\hline CCLI6 & Chemokine (C-C motif) ligand I6 & 5.02 \\
\hline$T N F$ & Tumor necrosis factor & 4.51 \\
\hline CCL2 & Chemokine ( $\mathrm{C}-\mathrm{C}$ motif) ligand 2 & 3.77 \\
\hline CXCL3 & Chemokine (C-X-C motif) ligand 3 & 3.00 \\
\hline CCLI3 & Chemokine (C-C motif) ligand I 3 & 2.98 \\
\hline CCL3 & Chemokine (C-C motif) ligand 3 & 2.94 \\
\hline CXCL5 & Chemokine (C-X-C motif) ligand 5 & 2.68 \\
\hline CCL4 & Chemokine ( $\mathrm{C}-\mathrm{C}$ motif) ligand 4 & 2.58 \\
\hline FOS & $\begin{array}{l}F B J \text { murine osteosarcoma viral } \\
\text { oncogene homolog }\end{array}$ & 2.33 \\
\hline LTA & Lymphotoxin A & 2.11 \\
\hline CCLI9 & Chemokine (C-C motif) ligand 19 & 1.99 \\
\hline$I L-I \beta$ & Interleukin-I $\beta$ & 1.99 \\
\hline CCL24 & Chemokine (C-C motif) ligand 24 & 1.92 \\
\hline CCL22 & Chemokine (C-C motif) ligand 22 & 1.90 \\
\hline IFN- $\gamma$ & Interferon gamma & 1.87 \\
\hline IL-23A & Interleukin-23, subunit alpha, p19 & 1.81 \\
\hline CXCL2 & Chemokine (C-X-C motif) ligand 2 & 1.70 \\
\hline TLR4 & Toll-like receptor 4 & 1.66 \\
\hline TLR2 & Toll-like receptor 2 & 1.64 \\
\hline IL-I5 & Interleukin-I5 & 1.61 \\
\hline LY96 & Lymphocyte antigen 96 & 1.55 \\
\hline B & $\begin{array}{l}\text { Genes with moderate changes } \\
\text { in expression }\end{array}$ & $0.76-1.49 x$ \\
\hline Gene & Gene name & $\begin{array}{l}\text { Change } \\
\text { x-fold }\end{array}$ \\
\hline$\overline{C C L 7}$ & Chemokine (C-C motif) ligand 7 & 1.41 \\
\hline RIPK2 & Receptor-interacting Ser-Thr kinase 2 & 1.40 \\
\hline CXCL2 & Chemokine (C-X-C motif) ligand 2 & 1.31 \\
\hline$C D / 4$ & Cluster of differentiation 14 & 1.22 \\
\hline CCL23 & Chemokine (C-C motif) ligand 23 & 1.20 \\
\hline CXCL9 & Chemokine (C-X-C motif) ligand 9 & 1.20 \\
\hline$T L R I$ & Toll-like receptor I & 1.12 \\
\hline CD40LG & Cluster of differentiation 40 ligand & 1.11 \\
\hline MYD88 & $\begin{array}{l}\text { Myeloid differentiation primary } \\
\text { response gene ( } 88 \text { ) }\end{array}$ & 1.07 \\
\hline CCL2I & Chemokine (C-C motif) ligand 21 & 1.07 \\
\hline TLR7 & Toll-like receptor 7 & 1.00 \\
\hline ILIORB & Interleukin- 10 receptor $B$ & 1.00 \\
\hline TIRAP & $\begin{array}{l}\text { Toll-interleukin-I receptor (TIR) } \\
\text { domain containing protein }\end{array}$ & 1.00 \\
\hline CSFI & Colony-stimulating factor I & 0.99 \\
\hline CCLII & Chemokine (C-C motif) ligand II & 0.99 \\
\hline TLR3 & Toll-like receptor 3 & 0.98 \\
\hline$N F-\kappa B$ & Nuclear factor kappa B & 0.96 \\
\hline CXCLIO & Chemokine (C-X-C motif) ligand 10 & 0.92 \\
\hline CCLI 7 & Chemokine (C-C motif) ligand I7 & 0.91 \\
\hline LTB & Lymphotoxin B & 0.90 \\
\hline TOLLIP & Toll interacting protein & 0.89 \\
\hline ILIRI & Interleukin-I receptor, type I & 0.89 \\
\hline
\end{tabular}

(Continued)
Table 2 (Continued)

\begin{tabular}{|c|c|c|}
\hline CCL5 & Chemokine ( $\mathrm{C}-\mathrm{C}$ motif) ligand 5 & 0.86 \\
\hline TLR6 & Toll-like receptor 6 & 0.86 \\
\hline ILIA & Interleukin-IA & 0.83 \\
\hline$B C L 6$, & B-cell/CCL, lymphoma 6 & 0.82 \\
\hline CEBPB & CCAAT/enhancer binding protein, $B$ & 0.76 \\
\hline $\mathrm{NR3Cl}$ & $\begin{array}{l}\text { Nuclear receptor superfamily } 3 \text {, } \\
\text { group C, member I }\end{array}$ & 0.76 \\
\hline C & $\begin{array}{l}\text { Genes with markedly decreased } \\
\text { expression }\end{array}$ & $\leq 0.75 x$ \\
\hline Gene & Gene name & $\begin{array}{l}\text { Decrease } \\
\text { x-fold }\end{array}$ \\
\hline NOS2 & Nitric oxide synthase 2 , inducible & 0.17 \\
\hline IL-8 & Interleukin-8 & 0.28 \\
\hline CXCLI & Chemokine (C-X-C motif) ligand I & 0.29 \\
\hline IL-IRN & Interleukin-I receptor antagonist & 0.31 \\
\hline CCR3 & Chemokine (C-C motif) receptor 3 & 0.32 \\
\hline FASLG & Fas ligand (TNF superfamily, member 6) & 0.35 \\
\hline CXCL6 & Chemokine (C-X-C motif) ligand 6 & 0.52 \\
\hline CCR2 & Chemokine (C-C motif) receptor 2 & 0.53 \\
\hline C3 & Complement component 3 & 0.55 \\
\hline IL-22 & Interleukin-22 & 0.57 \\
\hline C $3 A R I$ & Complement component 3 a receptor I & 0.58 \\
\hline PTGS2 & Prostaglandin-endoperoxide synthase 2 & 0.58 \\
\hline IL-I8 & Interleukin- /8 & 0.59 \\
\hline CD40 & Cluster of differentiation 40 & 0.60 \\
\hline IL-6R & Interleukin-6 receptor & 0.60 \\
\hline IL-IRAP & Interleukin-I receptor accessory protein & 0.63 \\
\hline CCR4 & Chemokine (C-C motif) receptor 4 & 0.65 \\
\hline IL-9 & Interleukin-9 & 0.66 \\
\hline ITGB2 & Integrin B2 & 0.69 \\
\hline CXCR4 & Chemokine (C-X-C), receptor 4 & 0.70 \\
\hline TLR5 & Toll-like receptor 5 & 0.74 \\
\hline CCR7 & Chemokine (C-C motif) receptor 7 & 0.75 \\
\hline
\end{tabular}

Notes: The linear difference of expression, or fold change, is compared between the control sample and the endoscopic dacryocystorhinostomy sample. (A) Markedly increased expression ( $\geq 1.5$-fold). (B) Moderate changes in expression (0.76-1.49fold). (C) Markedly decreased expression ( $\leq 0.75$-fold).

Abbreviation: qRT-PCR, quantitative reverse transcription polymerase chain reaction.

such as $C C L 2, C C L 3, I L-6, I L-1 \beta$, and $T N F-\alpha$, which were also strongly increased in samples from NLDO patients as compared with those from controls. In order to avoid overwhelming inflammation, $\mathrm{NF}-\mathrm{\kappa B}$ is kept under strict autoregulation. ${ }^{19}$ The dynamic regulation probably results in no visible increase in expression of mRNA for NF- $\mathrm{\kappa B}$ in EN-DCR patients.

In the present study, our success rate for primary EN-DCR was $60 \%$, which is lower than our previously reported rate of 93\%. ${ }^{15}$ This difference may be explained by the small patient population recruited for this study. Although symptomatic relief was achieved in our two failed patients, our strict criteria categorized these patients as failures because irrigation was unsuccessful. The lack of studies examining the inflammation restricts our understanding of the underlying mechanisms 
causing NLDO. Therefore, we propose that the present study provides new important information. The profile of investigated markers suggests that inflammation has passed from its initiation state, which is in accordance with the previous findings that long-lasting inflammation is present in NLDO. Since the main reason for failure of EN-DCR is scarring over the rhinostomy site, ${ }^{4,5}$ an antifibrotic drug able to target fibrogenic factors or block their receptors could be beneficial. Therefore, a potential target for therapy to control the progression of fibrosis is currently being sought. ${ }^{11}$ These potential inflammatory factors are promising candidates for future studies because they can be viewed as potential targets in the development of antifibrotic therapy intended for prevention of excessive scar formation.

\section{Conclusion}

The present study shows that expression of various inflammatory response-related genes is upregulated in the nasal mucosa of patients undergoing EN-DCR, but larger study populations are required to understand the details of these inflammatory responses.

\section{Author contributions}

Author contributions were as follows: EP, study planning, operations and clinical examination, manuscript writing; JMTH, analysis and interpretation of data, manuscript writing; MH, qRT-PCR measurements; AK, interpretation of data, manuscript writing; GS, study planning, manuscript writing; HT, study planning, manuscript writing; JS, study planning, manuscript writing; JN, manuscript writing; and $\mathrm{KK}$, study planning, manuscript writing, and economic support. All authors contributed toward data analysis, drafting and revising the paper and agree to be accountable for all aspects of the work.

\section{Acknowledgments}

This work was supported by special government grant to the Kuopio University Hospital, the Finnish Cultural Foundation and its North Savo Fund, the Finnish Eye Foundation, the Finnish Funding Agency for Technology and Innovation, the Health Research Council of the Academy of Finland, and the Päivikki and Sakari Sohlberg Foundation. The study sponsors had no role in the study design, data collection, analysis and interpretation, or writing of the report.

\section{Disclosure}

The authors report no conflicts of interest in this work.

\section{References}

1. Bartley GB. Acquired lacrimal drainage obstruction: an etiologic classification system, case reports, and a review of the literature. Part 3. Ophthal Plast Reconstr Surg. 1993;9(1):11-26.

2. Linberg JV, McCormick SA. Primary acquired nasolacrimal duct obstruction. A clinicopathologic report and biopsy technique. Ophthalmology. 1986;93(8):1055-1063.

3. Leong SC, Macewen CJ, White PS. A systematic review of outcomes after dacryocystorhinostomy in adults. Am J Rhinol Allergy. 2010;24(1): $81-90$.

4. Jokinen K, Karja J. Endonasal dacryocystorhinostomy. Arch Otolaryngol. 1974;100(1):41-44.

5. Allen KM, Berlin AJ, Levine HL. Intranasal endoscopic analysis of dacrocystorhinostomy failure. Ophthal Plast Reconstr Surg. 1988;4(3): 143-145.

6. Goldberg RA. Endonasal dacryocystorhinostomy: is it really less successful? Arch Ophthalmol. 2004;122(1):108-110.

7. Mauriello JA Jr, Palydowycz S, DeLuca J. Clinicopathologic study of lacrimal sac and nasal mucosa in 44 patients with complete acquired nasolacrimal duct obstruction. Ophthal Plast Reconstr Surg. 1992;8(1): $13-21$.

8. Paulsen FP, Thale AB, Maune S, et al. New insights into the pathophysiology of primary acquired dacryostenosis. Ophthalmology. 2001;108(12):2329-2336.

9. Heindl LM, Junemann A, Holbach LM. A clinicopathologic study of nasal mucosa in 350 patients with external dacryocystorhinostomy. Orbit. 2009;28(1):7-11.

10. Ozer O, Eskiizmir G, Unlu H, et al. Chronic inflammation: a poor prognostic factor for endoscopic dacryocystorhinostomy. Eur Arch Otorhinolaryngol. 2012;269(3):839-845.

11. Smirnov G, Pirinen R, Tuomilehto H, et al. Strong expression of HSP47 in metaplastic nasal mucosa may predict a poor outcome after primary endoscopic dacryocystorhinostomy: a prospective study. Acta Ophthalmol. 2011;89(2):e132-e136.

12. Taguchi T, Razzaque MS. The collagen-specific molecular chaperone HSP47: is there a role in fibrosis? Trends Mol Med. 2007;13(2): $45-53$.

13. Saklad M. Grading of patients for surgical procedures. Anesthesia. 1941;2:28.

14. Lund VJ, Mackay IS. Staging in rhinosinusitus. Rhinology. 1993;31(4): 183-184.

15. Smirnov G, Tuomilehto H, Kokki H, et al. Symptom score questionnaire for nasolacrimal duct obstruction in adults - a novel tool to assess the outcome after endoscopic dacryocystorhinostomy. Rhinology. 2010;48(4):446-451.

16. Smirnov G, Tuomilehto H, Terasvirta M, et al. Silicone tubing after endoscopic dacryocystorhinostomy: is it necessary? Am J Rhinol. 2006;20(6):600-602.

17. Winer J, Jung CK, Shackel I, Williams PM. Development and validation of real-time quantitative reverse transcriptase-polymerase chain reaction for monitoring gene expression in cardiac myocytes in vitro. Anal Biochem. 1999;270(1):41-49.

18. Sawa Y, Tsuruga E. The expression of E-selectin and chemokines in the cultured human lymphatic endothelium with lipopolysaccharides. J Anat. 2008;212(5):654-663.

19. Collins T, Read MA, Neish AS, et al. Transcriptional regulation of endothelial cell adhesion molecules: NF-kappa B and cytokine-inducible enhancers. FASEB J. 1995;9(10):899-909.

20. Barnes TC, Anderson ME, Moots RJ. The many faces of interleukin-6: the role of IL-6 in inflammation, vasculopathy, and fibrosis in systemic sclerosis. Int J Rheumatol. 2011;2011:721608.

21. Oikonomou N, Harokopos V, Zalevsky J, et al. Soluble TNF mediates the transition from pulmonary inflammation to fibrosis. PLoS One. 2006;1:e108. 
22. Harada A, Sekido N, Akahoshi T, et al. Essential involvement of interleukin-8 (IL-8) in acute inflammation. J Leukoc Biol. 1994;56(5): 559-564.

23. Howard OM, Dong HF, Shirakawa AK, et al. LEC induces chemotaxis and adhesion by interacting with CCR1 and CCR8. Blood. 2000;96(3): $840-845$.

24. Smith DF, Galkina E, Ley K, et al. GRO family chemokines are specialized for monocyte arrest from flow. Am J Physiol Heart Circ Physiol. 2005;289(5):H1976-H1984.
25. Garcia-Zepeda EA, Combadiere C, Rothenberg ME, et al. Human monocyte chemoattractant protein (MCP)-4 is a novel CC chemokine with activities on monocytes, eosinophils, and basophils induced in allergic and nonallergic inflammation that signals through the $\mathrm{CC}$ chemokine receptors (CCR)-2 and -3. J Immunol. 1996;157(12):5613-5626.

26. Maurer M, von Stebut E. Macrophage inflammatory protein-1. Int J Biochem Cell Biol. 2004;36(10):1882-1886.

27. Newton K, Dixit VM. Signaling in innate immunity and inflammation. Cold Spring Harb Perspect Biol. 2012;4(3). pii:a006049.

\section{Publish your work in this journal}

Clinical Ophthalmology is an international, peer-reviewed journal covering all subspecialties within ophthalmology. Key topics include: Optometry; Visual science; Pharmacology and drug therapy in eye diseases; Basic Sciences; Primary and Secondary eye care; Patien Safety and Quality of Care Improvements. This journal is indexed on

Submit your manuscript here: http://www.dovepress.com/clinical-ophthalmology-journal

\section{Dovepress}

PubMed Central and CAS, and is the official journal of The Society of Clinical Ophthalmology (SCO). The manuscript management system is completely online and includes a very quick and fair peer-review system, which is all easy to use. Visit http://www.dovepress.com/ testimonials.php to read real quotes from published authors. 